PENELITIAN

\title{
PENGARUH STRATEGI PENANGANAN ANAK TEMPER TANTRUM MELALUI TERAPI PERMAINAN PUZZLE
}

\author{
Fitriana* Suci Lanavia* \\ Jurusan Kebidanan Poltekkes Tanjungkarang \\ Email: fitrianarayyana@gmail.com
}

\begin{abstract}
Tantrum terjadi sekurangnya sekali seminggu pada 50-80 persen anak prasekolah. Berdasarkan hasil prasurvei yang i lakukan pada bulan November Tahun 2017 di RA Permata Bunda dari 10 anak terdapat 7 anak (70\%) yang mengalami temper tantrum dibandingkan di TK Istiqlal dari 10 anak hanya terdapat 4 anak (40\%) yang mengalami temper tantrum. Tujuan dari penelitian ini adalah ada pengaruh strategi penanganan anak temper tantrum melalui terapi permainan puzzle di Yayasan RA Permata Bunda Rajabasa Bandar Lampung Tahun 2018. Jenis penelitian kuantitatif, rancangan penelitian analitik dengan pendekatan quasi eksperimen, Populasi dalam penelitian ini adalah semua anak yang ada di Yayasan RA Permata Bunda Rajabasa Bandar Lampung, sampel dalam penelitian ini sebanyak 30 sampel. Teknik pengambilan sampel total populasi. Analisis data menggunakan uji Uji T-Test. Hasil penelitian didapatkan ratarata temper tantrum sebelum diberikan terapi permainan puzzle yaitu sebesar 13,26 dan rata-rata temper tantrum setelah diberikan terapi permainan puzzle yaitu sebesar 8,00. Pengaruh strategi penanganan anak temper tantrum melalui terapi permainan puzzle di Yayasan RA Permata Bunda Rajabasa Bandar Lampung Tahun 2018, analisa data menggunakan uji t didapat $p$ value $0,000<a$ 0,05. Saran dalam penelitian ini agar guru memberikan terapi permainan puzzle sebagai salah satu cara untuk penanganan anak yang mangalami temper tantrum. Agar terapi puzzle dapat diterpakan sebagai sarana bermain bagi anak.
\end{abstract}

Kata Kunci: Terapi puzzle, Temper Tantrum

\section{LATAR BELAKANG}

Temper tantrum adalah ledakan emosi yang kuat yang terjadi ketika anak balita merasa lepas kendali. Tantrum adalah demonstrasi praktis dari apa yang dirasakan oleh anak dalam dirinya (Zaviera, 2008).

Hampir semua tantrum terjadi ketika anak sedang bersama orang yang paling dicintainya. Tingkah laku ini biasanya mencapai titik terburuk pada usia 18 bulan hingga tiga tahun, dan kadang masih ditemui pada anak usia lima atau enam tahun, namun hal tersebut sangat tidak biasa dan secara bertahap akan menghilang.

Saat anak mengalami tantrum, banyak orangtua yang beranggapan bahwa hal tersebut merupakan sesuatu yang negatif, dan pada saat itu juga orangtua bukan saja bertindak tidak tepat tetapi juga melewatkan salah satu kesempatan yang paling berharga untuk membantu anak menghadapi emosi yang normal (marah, frustrasi, takut, jengkel) secara wajar dan bagaimana bertindak dengan cara yang tepat sehingga tidak menyakiti diri sendiri dan orang lain ketika sedang merasakan emosi tersebut.

Akibat yang ditimbulkan dari temper tantrum ini cukup berbahaya, misalnya anak yang melampiaskan kekesalannya dengan cara berguling-guling dilantai yang keras dapat menyebabkan anak menjadi cedera. Anak yang melampiaskan amarahnya dapat menyakiti dirinya sendiri, menyakiti orang lain atau merusak benda yang ada disekitarnya. Jika benda-benda yang ada disekitar anak merupakan benda keras maka akan sangat berbahaya karena anak dapat tersakiti dan mengalami cedera akibat dari tindakan tantrumnya.

Anak yang mengalami tantrum ini sebenarnya digunakan untuk mencari 
perhatian sehingga orangtua sebisa mungkin untuk menjauhkan anak dari perhatian umum ketika mengalami tantrum dan sekaligus menjauhkan anak dari bendabenda yang berbahaya agar anak tidak mengalami cedera.

Tantrum yang tidak diatasi dapat membahayakan fisik anak, selain itu anak tidak akan bisa mengendalikan emosinya atau anak akan kehilangan kontrol dan akan lebih agresif. Hal ini akan mengakibatkan anak tidak bisa menghadapi lingkungan luar, tidak bisa beradaptasi, tidak bisa mengatasi masalah, tidak bisa mengambil keputusan dan anak tidak akan tumbuh dewasa, karena melewati tantrum akan membuat anak tumbuh dewasa

Banyak cara atau terapi terapi yang di gunakan untuk menangani anak yang menderita gangguan tempertantrum salah satunya yaitu dengan terapi permainan,salah satunya adalah permainan puzzle

Manfaat dari permainan puzzle yaitu dapat mempengaruhi kecerdasan kognitf pada anak. Dengan bermain puzzle anak dapat melatih intelegensi dalam memecahkan masalah. Permainan puzzle juga melibatkan koordinasi mata dan tangan dan anak dapat bereksplorasi menurut kemampuan dan minatnya (Dariyo, 2007).

Hasil prasurvei yang telah peneliti lakukan pada bulan November Tahun 2017 di RA Permata Bunda dari 10 anak terdapat 7 anak (70\%) yang mengalami temper tantrum dibandingkan di TK Istiqlal dari 10 anak hanya terdapt 4 anak (40\%) yang mengalami temper tantrum.

\section{METODE}

Jenis penelitian kuantitatif, rancangan penelitian analitik dengan pendekatan quasi eksperimen, Populasi dalam penelitian ini adalah semua anak yang ada di Yayasan RA Permata Bunda Rajabasa Bandar Lampung, sampel dalam penelitian ini sebanyak 30 sampel. Teknik pengambilan sampel purposive sampling, analisis data menggunakan uji Uji T-Test.

\section{HASIL}

Nilai Kolmogorov-Smirnov temper tantrum sebelum dan sesudah diberikan perlakuan dengan metode puzzle data kedua variabel dalam penelitian ini berdistribusi Normal.

\section{Analisis Univariat}

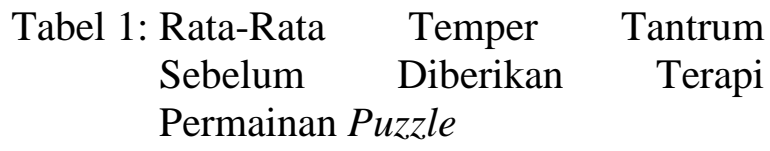

\begin{tabular}{lllllll}
\hline \multicolumn{1}{c}{ Variabel } & $\mathrm{n}$ & Mean Med & SD & Min & Max \\
\hline $\begin{array}{l}\text { Temper tantrum } \\
\text { anak sebelum } \\
\text { intervensi }\end{array}$ & 30 & 13,26 & 14 & 1,054 & 12 & 15 \\
\hline
\end{tabular}

Diketahui bahwa dari 30 responden penelitian, diperoleh hasil nilai mean atau nilai rata-rata temper tantrum anak sebelum intervensi sebesar 13,17 dengan nilai median 13,50, standar deviasi sebesar 1,054, hasil rata-rata terendah atau hasil minimal yaitu sebesar 12 dan

hasil maximal sebesar 15 .

Tabel 2: Rata-Rata Temper Tantrum Setelah Diberikan Terapi Permainan Puzzle

\begin{tabular}{lllllll}
\hline \multicolumn{1}{c}{ Variabel } & $\mathrm{n}$ & Mean & Med & SD & Min Max \\
\hline $\begin{array}{l}\text { Temper tantrum } \\
\text { anak sebelum } \\
\text { intervensi }\end{array}$ & 30 & 8 & 8 & 0,905 & 7 & 9 \\
\hline
\end{tabular}

Diketahui bahwa dari 30 responden penelitian, diperoleh hasil nilai mean atau nilai rata-rata temper tantrum anak setelah intervensi sebesar 8,00 dengan nilai median 8,00 , standar deviasi sebesar 0,905 , hasil ratarata terendah atau hasil minimal yaitu sebesar 7 dan hasil tekanan darah tertinggi atau hasil maksiimal sebesar 9 . 


\section{Analisis Bivariat}

Tabel 3: Perbedaan Temper Tantrum Sebelum dan Sesudah Terapi Permainan Puzzle

\begin{tabular}{ccccc}
\hline Tempertantrum & $\mathrm{n}$ & $\mathrm{SD}$ & $\mathrm{SE}$ & $\begin{array}{c}p \\
\text { value }\end{array}$ \\
\cline { 1 - 4 } Sebelum Intervensi & 30 & 1,054 & 0,220 & \multirow{2}{*}{0.000} \\
\cline { 1 - 4 } Sesudah Intervensi & 30 & 0,905 & 0,189 & \\
\hline
\end{tabular}

Berdasarkan tabel 3 dapat hasil uji $t$ didapat $p$-value $0,000<\alpha \quad(0,05)$ artinya $\mathrm{H} 0$ ditolak dan Ha diterima, yang berarti ada Pegaruh Strategi Penanganan Anak Temper Tantrum Melalui Terapi Permainan Puzzle.

\section{PEMBAHASAN}

Berdasarkan hasil penelitian diatas dapat diketahui bahwa dari 30 responden penelitian, diperoleh hasil nilai mean atau nilai rata-rata temper tantrum anak sebelum intervensi sebesar 13,17 dengan nilai median 13,50, standar deviasi sebesar 1,054, hasil rata-rata terendah atau hasil minimal yaitu sebesar 12 dan hasil maximal sebesar 15 , sedangkan nilai rata-rata temper tantrum anak setelah intervensi sebesar 7,97 dengan nilai median 8,00 , standar hasil pengukuran temper tatum rata-rata terendah atau hasil minimal yaitu sebesar 7 dan hasil tekanan darah tertinggi atau hasil maximal sebesar 9 .

Hasil penelitian ini sejalan dengan penelitian yang telah dilakukan oleh Almunawar Kristiyanto tahun (2013) dengan judul Strategi Penanganan Anak Temper Tantrum Melalui Terapi Permainan Puzzle di TK Desa Jatingarang, Weru, Sukoharjo, dengan hasil penelitian menunjukkan bahwa Udin sering bermain sendiri saat pembelajaran, tidak mampu memperhatikan konsentrasinya dalam waktu yang lama, saat di beri tugas ia menyelesaikan setengahsetengah lalu menggangu temannya setelah diterapi Udin sudah mampu mengontrol emosinya, tidak menggangu temannya, fokus terhadap satu kegiatan dan konsentrasi.

Menurut pendapat peneliti bahwa temper tantrum yang dimiliki anak berbedabeda hal tersebut dikarenakan oleh faktor keluarga. Dimana pada faktor keluaraga dalam penelitian ini ada pola asuh orang tua, cara orangtua mengasuh anak juga berperan untuk menyebabkan tantrum. Anak yang terlalu dimanjakan dan selalu mendapat apa yang ia inginkan, bisa tantrum ketika suatu kali permintaannya ditolak. Bagi anak yang terlalu dan didominasi oleh orantuanya, sekali waktu anak bisa jadi bereaksi menentang dominasi orangtua dengan perilaku tantrum. Orangtua yang mengasuh anak secara tidak konsisten juga bisa menyebabkan anak tantrum. Pola asuh orangtua dalam hal ini sebenarnya lebih pada bagaimana orangtua dapat memberikan contoh atau teladan kepada anak dalam setiap bertingkah laku karena anak akan selalu meniru setiap tingkah laku orangtua.

Selanjutnya berdasarkan analisis bivariat menggunakan uji t didapat $p$-value $0,000<\alpha(0,05)$ artinya $\mathrm{H} 0$ ditolak dan $\mathrm{Ha}$ diterima, yang berarti ada Pegaruh Strategi Penanganan Anak Temper Tantrum Melalui Terapi Permainan Puzzle.

Menurut Purnamasari (2005) menyebutkan bahwa setiap anak yang setidaknya telah berusia 18 bulan hingga tiga tahun dan bahkan lebih akan menentang perintah dan menunjukkan individualitasnya sekali waktu. Hal ini merupakan bagian normal balita karena mereka terus menerus mengeksplorasi dan mempelajari batasan batasan disekeliling

Anak akan menunjukkan berbagai macam tingkah laku, seperti keras kepala dan membangkang karena sedang mengembangkan kepribadian dan otonominya. Tantrum juga merupakan cara normal untuk mengeluarkan semua perasaan yang menumpuk

Banyak cara atau terapi yang di gunakan untuk menangani anak yang menderita gangguan tempertantrum salah satunya yaitu dengan terapi permainan 
bermain merupakan bagian masa kanakkanak yang merupakan media untuk memfasilitasi ekspresi bahasa, ketrampilan komunikasi, perkembangan emosi, keterampilan sosial, keterampilan pengambilan keputusan dan perkembangan kognitif pada anak-anak. Bermain pada anak-anak seperti berbicara pada orang dewasa. dimana salah satu contoh metode bermain adalah dengan bermain puzzle. Dengan terapi permainan ini anak akan merasa nyaman dan senang sehingga anak tidak menyadari bahwa anak sedang di berikan terapi.

Hasil penelitian ini sejalan dengan penelitian yang telah dilakukan oleh Almunawar Kristiyanto (2013) dengan judul Strategi Penanganan Anak Temper Tantrum Melalui Terapi Permainan Puzzle di TK Desa Jatingarang, Weru, Sukoharjo, dengan hasil penelitian menunjukkan bahwa Bagi Dika selalu bergerak atau tidak mau diam, Dika termasuk anak yang manja selalu ingin di dahulukan. Apabila hal yang diinginkannya tidak dituruti Dika marah bahkan membanting benda yang ada di sekitarnya, setelah medapat terapi mau bermain puzzle, sudah mampu mengontrol emosinya, serta fokus terhadap puzzle, dan tidak manja.

Menurut pendapat peneliti berdasarkan hasil penelitian menunjukan bahwa temper tantrum yang dimiliki anak berbeda-beda hal tersebut dikarenakan oleh faktor keluarga. Dimana pada faktor keluaraga dalam penelitian ini ada pola asuh orang tua, cara orangtua mengasuh anak juga berperan untuk menyebabkan tantrum.

Seorang anak perlu melihat bahwa orang dewasa dapat mengatasi frustasi dan kekecewaan tanpa harus lepas kendali, dengan demikian anak dapat belajar untuk mengendalikan diri. Orangtua jangan mengharapkan anak dapat menunjukkan sikap yang tenang jika selalu memberikan contoh yang buruk.

\section{KESIMPULAN}

Berdasarkan hasil penelitian dapat disimpulkan bahwa rata-rata tempertantrum sebelum diberikan terapi permainan puzzle sebesar 13,26 dan setelah diberikan terapi permainan puzzle sebesar 8,00. Hasil analisis lebih lanjut diketahui bahwa ada perbedaan tempertantrum sebelum dan sesudah terapi bermain puzzle ( $p$-value 0,000). Dengan demikian, maka disimpulkan ada pengaruh permainan puzzel terhadap tempertantrum.

Berdasarkan kesimpulan tersebut, maka disarankan agar guru dan orang tua memberikan dapat terapi permainan puzzle sebagai salah satu cara untuk penanganan anak yang mangaalami temper tantrum.

\section{DAFTAR PUSTAKA}

Almunawar Kristiyanto. (2013). StrategiPenanganan Anak Temper Tantrum Melalui Terapi Permainan Puzzle Di Tk Desa Jatingarang, Jatingarang, Weru, Sukoharjo

Dariyo, Agoes. (2007). Psikologi Perkembangan Anak Tiga Tahun Pertama. Bandung: PT.Refilea Aditama.

Zaviera. (2008). Mengenali dan memahami tumbuh kembang anak. Yogyakarta: Kata 